\title{
Bairoch revisited: tariff structure and growth in the late nineteenth century
}

\author{
ANTONIO TENA-JUNGUITO \\ Department of Economic History and Institutions, Universidad Carlos III de \\ Madrid, C/. Madrid I26-28903 Getafe, Madrid, antonio.tena@uczm.es
}

This article revisits Bairoch's hypothesis that in the late nineteenth century tariffs were positively associated with growth, as recently confirmed by a new generation of quantitative studies (see O'Rourke 2000; Jacks 2006; Clemens and Williamson 2002, 2004). This article highlights the importance of the structure of protection in the relation between trade policy and its potential growth-promoting impact. Evidence is based on a new database on industrial tariffs for the I870s. The results show that income, factor endowment and policy independence are important for explaining regional asymmetries between tariffs and growth. At a global level, increased protection, measured by total and average tariffs on manufactures, implied more unskilled inefficient protection and less growth, and this is especially true for the poor countries in the late nineteenth century. Protection was only positive for a 'rich club' if we include in this group new settler countries, which grew rapidly in the late nineteenth century and imposed high tariffs mainly for fiscal reasons.

\section{Introduction}

In the explanation of economic growth, any attempt to isolate one single factor among the complex mix is a hard task, and this certainly applies to the economic impact of commercial policies too. Many economic historians have supported the idea that during the late nineteenth century protection was instrumental to the development of continental Europe. Bairoch's (1972, 1976, 1989, 1993) hypothesis that tariffs were positively associated with growth mainly applied to European countries, but it has also been extended to other high-tariff land-abundant countries like the rich European

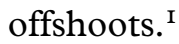

Recent econometric studies carried out by O'Rourke (2000) and Jacks (2006) tend to confirm propositions regarding the positive correlation

I This positive relation between tariffs and growth in Europe in the late nineteenth century has been sustained by many authors, including Milward and Saul (1977) and Pollard (I982), but notably by Bairoch (1972, I976, I989, I996). For an extended discussion on the good reputation of late nineteenth-century protectionism, see Tena (2005). 
between tariffs and growth in the late nineteenth century. ${ }^{2}$ Both works use a limited sample of io countries, mostly rich European or land-abundant countries with good institutions, and this fact has been criticized, even if they are more concerned with exploring the variation in the time series of economic growth than with analysing cross-sectional influence. Other studies that follow a similar time-series strategy point out that the relationship between average tariffs and growth (significant or not significant, positive or negative) depends crucially on the countries included in the sample. A larger sample of countries has shown that the correlation between tariff average and growth might vary considerably in different countries, according to different levels of wealth and degrees of political independence (see Williamson 2006b). ${ }^{3}$ Likewise, Irwin (2002b) shows that rich land-abundant countries may be outliers in the relation between tariffs and growth, because they often relied on customs duties to generate a large proportion of their government revenue: they tended to impose high tariffs, but without following an importsubstituting extrategy. Tena $(2005,2006)$ remarks that the rich European tariff average is often distorted by revenue tariffs not designed to protect domestic producers, and that we should focus on the relation between manufacture tariffs and growth.

The most notable feature of this historical literature is its reliance on economy-wide average measures of protection. On one side, these data are readily available for a wide variety of countries, and average tariffs are easily calculated: all one needs to do is to divide total customs revenue by the total value of imports. On the other side, the simplicity of tariff averages makes it impossible to reach a deeper understanding of the causal mechanism linking tariffs and growth. In fact, as De Long (1995) and Irwin (2001a) emphasized for the late nineteenth century, the central question to investigate here is how tariffs alter domestic relative prices in order to shift resource allocation between higher- and lower-productivity sectors. In this case the emphasis will be put on the dynamics of economies of scale, learning-by-doing, and technical innovation that various sectors can develop as a consequence of temporal protection.

${ }^{2}$ Even if O'Rourke diverges from Bairoch on many points, it is generally agreed that in the late nineteenth century tariffs and growth were positively associated: 'It appears that Bairoch's hypothesis (that tariffs were positively associated with growth in the late nineteenth century) holds remarkably well, when tested with recently available data, and when controlling for other factors influencing growth' (O'Rourke 2000, p. 473).

3 O'Rourke (2000, p. 478) remembers that: 'Lessons from the late nineteenth century core cannot automatically be extended to the late nineteenth century periphery: as always, more research on Southern and Eastern Europe, as well as the developing world, should be high on the agenda of cliometricians.' For the twentieth century see Dejong and Ripoll (2006); and for both the nineteenth and twentieth centuries see Clemens and Williamson (200I, 2004) and Vamvakidis (2002). 
In a very recent paper, Lehman and O'Rourke (2008), asking whether agricultural and industrial tariffs had the same impact on growth in the late nineteenth century, found robust evidence that manufacture, rather than agricultural tariffs, was related to growth. Their paper uses panel data, but limits the analysis to the same 'rich countries club' as O'Rourke (2000). Also, it focuses on five-year periods, picking up the short- to medium-run impact of protection rather than the longer-run effects (p. I4).

This article addresses the same issue but differs from the earlier literature in two respects. Firstly, we focus on the relation between efficient or inefficient tariff structures and long-run growth; secondly, we pay special attention to the different levels and geographical diversity of tariff structures around the world. This approach is made possible because we use a new and improved database which expands the number of countries, and offers a much more detailed disaggregation of manufacture tariffs ranked according to their skill intensity.

The article is structured as follows. The next section provides a general view of the relevance of the issue of regional asymmetry in the tariff-growth debate. Section 3 presents the intuitive model which relates tariff structure and growth, based on total tariff average, industrial tariff average, and the industrial skill tariff bias. Section 4 describes the sources and the variables used in the new database employed in this study. Section 5 discusses the main results of the correlation model, while the last section looks at how, in general, these results match the model predictions that countries with relatively higher tariffs in industry grow more slowly, apparently because high-tariff countries protected the non-skill-intensive sectors more than skill-intensive ones. The last section provides some concluding remarks, including the relevance of these findings in rejecting some of the interpretations offered by the previous literature.

\section{Did tariff structure explain regional asymmetries in the tariff-growth relation?}

The starting point is the confirmation and discussion of the regionally asymmetrical relationships between tariff average and growth discovered by Williamson et al. The tariff-growth relationship may be ambiguous because high tariffs in sectors with positive externalities may induce high rates of growth, while high tariffs in sectors with no positive externalities may induce low rates of growth. So, in theory, there is no reason to find a systematically unambiguous relationship between average tariffs and growth in different groups of countries, and regional asymmetry may be partially explained by different tariff structures.

This article assumes that in the late nineteenth century the regional asymmetries were mainly influenced by the starting level of income per 
capita, relative factor abundance and political independence. The division between rich and poor countries is a general proxy for different economic structures and institutional factors that may determine both the tariff structure bias and the relationship between tariffs and growth. Rich nations in Europe, with good institutions, were able to develop tariff policies which was less dependent on pressure groups. That would imply moderate and efficient tariffs on manufactured products. ${ }^{4}$ The tariff policies of politically independent poor countries, with less transparent institutions, weak enforcement of political rights, and lower parliamentary and executive independence, instead, were more likely to be influenced by lobbies. The result would be a policy of relatively higher, but more inefficient, tariffs in industry (biased in favour of non-competitive industrial sectors without progrowth effects). Land-abundant new settlers tended to impose high tariffs for reasons involving public finance and political economy. ${ }^{5}$ In terms of public finance, the taxation of imported goods reduced the cost of tax compliance in relation to other alternatives, and this is especially true for countries with low population density. Other means of raising revenue (excise taxes, land taxes, income taxes and the like) simply may not have been as feasible or as easy to enforce in countries with a widely dispersed population, particularly in the late nineteenth century. In terms of political economy, if a significant share of the population owns land (or if the government is controlled by landowners), they may have the inclination and the opportunity to avoid direct taxes on land in favour of high taxes on high-revenue-generating imported products or manufactured luxury goods. ${ }^{6}$

The picture was very different in the European colonies in Africa and Asia that implemented typical free-trade policies, normally imposed by their metropolis. Many of these countries, which had created tightly closed economies in the mid nineteenth century, became pro-global, low-tariff countries at the end of the century. ${ }^{7}$ Even independent countries such as Japan or China, under British influence, adopted treaties which limited their

${ }^{4}$ Core European countries had moderate manufacture tariffs and high revenue tariffs levied on just a few key primary commodities (such as alcoholic beverages, coffee and tea, sugar and tobacco). Revenue tariffs may have some protective effects but affect growth differently than broadly based tariffs designed to protect domestic producers (Tena 2006).

5 This argument is developed by Irwin (2002b). In that paper (figures 3 and 4), Irwin shows the existence of a clear positive association between land abundance (ratio of productive land over population) and either trade tax dependence (ratio of customs revenue over total revenue) or total tariff average. This evidence supports the idea that in these cases, high tariffs were not based upon an import substitution strategy.

${ }^{6}$ See Irwin (2002b) and Bértola and Williamson (2006).

${ }^{7}$ Following Bairoch (1989), countries like Abyssinia, Afghanistan, China, Iran, Japan, Liberia, Siam, the Arabian Peninsula and Turkey (Ottoman Empire), which were not formal colonies at the end of the nineteenth century, shared one important characteristic:

“"European Powers" obliged them, directly or indirectly, to open up their national markets' (p. I55). 
tariffs to 5 per cent in the second half of nineteenth century. Similarly, other Asian countries, such as India and Indonesia, were forced by their colonial masters to adopt liberal trade policies. Also in Africa, even if French, Portuguese and Italian colonies typically discriminated in favour of their respective colonial power, the progressive extension of European control resulted, in general terms, in a further diffusion of liberal trade policies at the end of the nineteenth century. ${ }^{8}$ This partial exogenous determination of their commercial policy would reduce the influence of local pressure groups, which in theory would press for higher tariffs, and would lead to a more neutral incidence of tariffs on the assignment of resources. ${ }^{9}$

Consequently, the question of whether a significant relationship between initial tariff average and growth exists, and whether this relationship is positive or negative, depends critically on the countries included in the sample.

In order to assess regional degrees of protection and their relation to growth we first provide a graphical analysis of the correlation between the initial degree of protection and the subsequent rate of growth. The initial tariff average used here, and in previous works, is measured as customs revenues divided by the total value of imports for the years I865-75; accumulated GDP per capita growth for $1870-1913$ is given in 1990 international Geary-Khamis dollars, following Maddison (200I). The world has been divided between rich and poor according to arbitrary but explicit criteria: those countries which, in I870, had a Maddison GDP per capita below half of that of the richest country in the world (the United Kingdom) are classified as 'poor'. In addition, taking into account what has been said above, a subdivision has been introduced for the rich, separating land-abundant countries from the rest (according to the established literature). At the same time, poor countries have been divided according to their tariff policy independence (in line with Williamson (2006) and Bairoch (1976, I989)). As a consequence, this article analyses 42 countries divided into four geographical regions (see Appendix, Table A2): 8 rich European countries (DumRegr: Austria, Belgium, Denmark, France, Germany, the Netherlands, Switzerland and the United Kingdom); 6 rich new settlers (DumReg2: Argentina, Australia,

${ }^{8}$ See Findlay and O'Rourke (2007, p. 40I): 'Countries like Japan gradually increase their tariff beginning in I889, but tariffs remained low prior to I9II, when the first autonomous (and protectionist) tariff was introduced (see Bairoch I989, p.I57).'

9 Other authors, including Bairoch (1989), and, more recently, Williamson (2006b) and Findlay and O'Rourke (2007), mentioned the importance of free colonial trade policy in the process of deindustrializing the colonies. But this debate is still open: 'these trade laws led first to the disappearance of existing crafts and later curbed the process of reindustrialization' (Bairoch I989, p. I27). Global terms of trade forces produced rising primary product specialization and de-industrialization in colonial countries at the end of the nineteenth century (see Lewis 1989 and Williamson 2006b). 


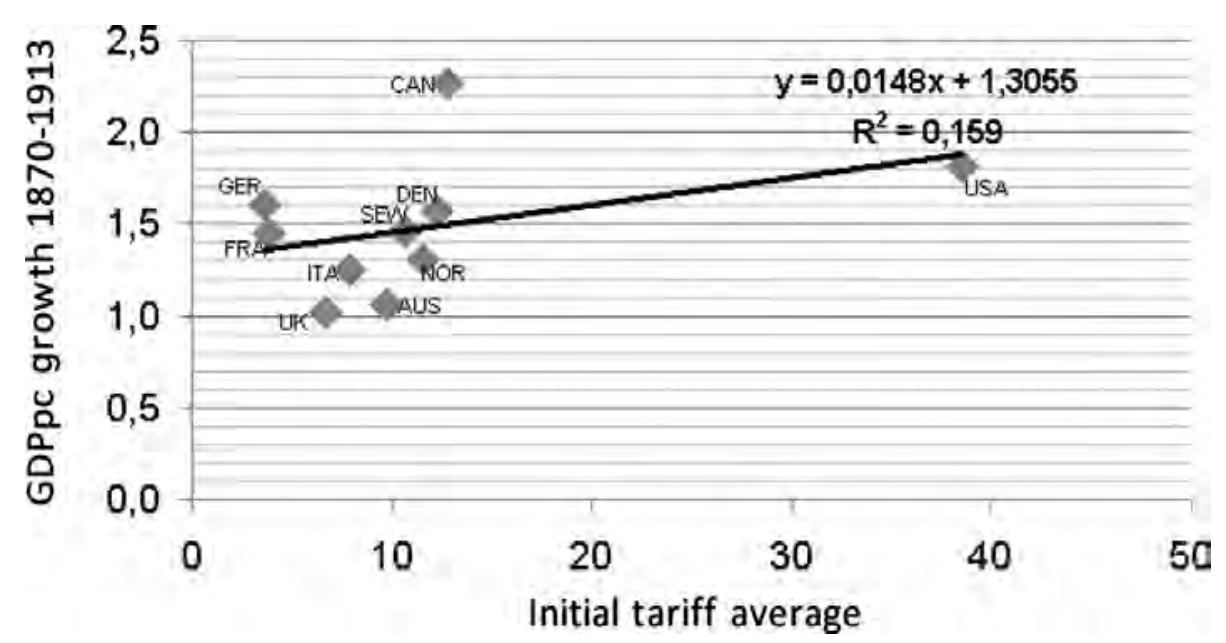

Figure I. Association between initial tariff average and GDP pc growth, I870-I9I3: sample of countries (O'Rourke 2000)

Source: Initial tariff $(75 \mathrm{NT})$ and GDP growth (7013GDPGR) in Appendix, Table A2.

Canada, New Zealand, Uruguay and the USA); I4 poor politically independent countries from the European periphery and Latin America (DumReg3: Greece, Hungary, Italy, Norway, Portugal, Romania, Russia, Spain, Sweden, Serbia, Brazil, Colombia, Cuba and Peru) and I4 poor politically dependent countries, most of them African and Asian colonies and protectorates (DumReg4: Burma, Ceylon, China, Egypt, India, Indonesia, Jamaica, Japan, Morocco, the Philippines, South Africa, Thailand, Tunisia and Turkey). As Table A2 in the Appendix shows, we do not have a complete dataset for all countries listed: therefore, for some regressions the number of observations varies from a minimum of 28 to a maximum of 38. ${ }^{10}$

To emphasize the regional asymmetry of the tariff-growth association, we first provide Figures I and 2, which confirm the positive association between the initial tariff average in $1865-75$ and real GDP per capita growth between I870 and I9I3, for the same group of countries used by O'Rourke (2000) and Jacks (2006) respectively. O'Rourke uses Australia, Canada, Denmark, France, Germany, Italy, Norway, Sweden, the United Kingdom and the United States, whereas Jacks uses Austria-Hungary, Belgium,

Io Argentina has been included in the group of rich new settlers, despite the fact that its GDPpc in I870 was slightly below half UK GDPpc in the same year, according to Maddison (2003). This is because Argentina is generally considered a rich new settler that has similar characteristics to an expansionist economy with strong imports of labour and capital and trade tax dependence. See O'Rourke and Williamson (I999), Irwin (2002b). 


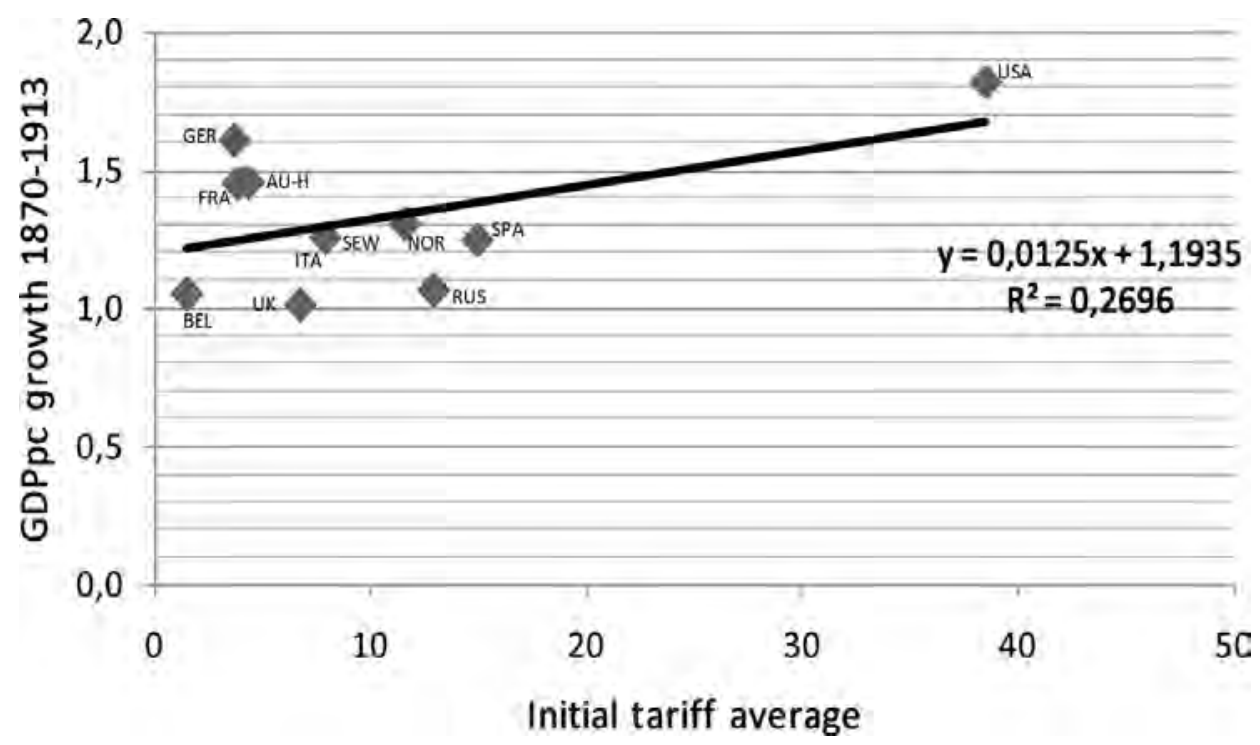

Figure 2. Association between initial tariff average and GDP, 1870I9I3: sample of countries (Facks 2006)

Source: Initial tariff (75NT) and GDP growth (7013GDPGR) in Appendix, Table A2.

France, Germany, Italy, Norway, Russia, Spain, the United Kingdom and the United States. It is important to take into account that most of the countries included in the sample are rich European and land-abundant countries. The selection of the country sample is apparently arbitrary and solely determined by the availability of historical data. In fact, it has been criticized by several authors (see Irwin (2002a,b), Williamson (2006b) and Tena (2006)). The strong bias towards rich countries typical of the previous literature is confirmed by using an alternative sample explicitly containing only rich countries (new settler and European countries), as shown in Figure 3. In both cases the regression is strongly influenced by the tariff-growth data of the USA.

As Figure 4 shows, however, once the whole sample of 38 world countries is considered, no positive or negative association between tariffs and growth emerges. A better representation of the world including rich and poor with colonies and independent developing countries thus provides a different picture of the tariff-growth relationship. Following Clemens and Williamson (200I, 2004) and Williamson (2006a), the strategy of this study is to accept the existence of regional asymmetry, and to propose an organization of world countries in clubs following the criteria mentioned above. Thus, the poor are divided according to their political independence, or, in other words, their capacity to develop an independent commercial policy from the metropolis. 


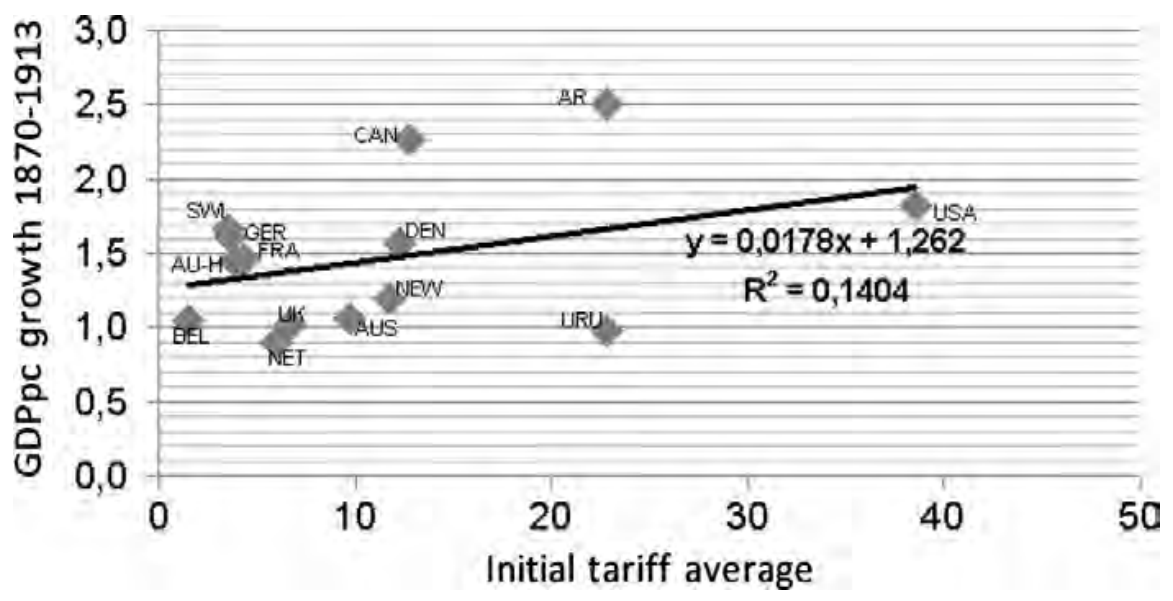

Figure 3. Association between initial tariff average and GDP $p c$ growth, 1870-1913: rich countries (European core and rich, landabundant countries)

Source: Initial tariff (75NT) and GDP growth (7013GDPGR) in Appendix, Table A2.

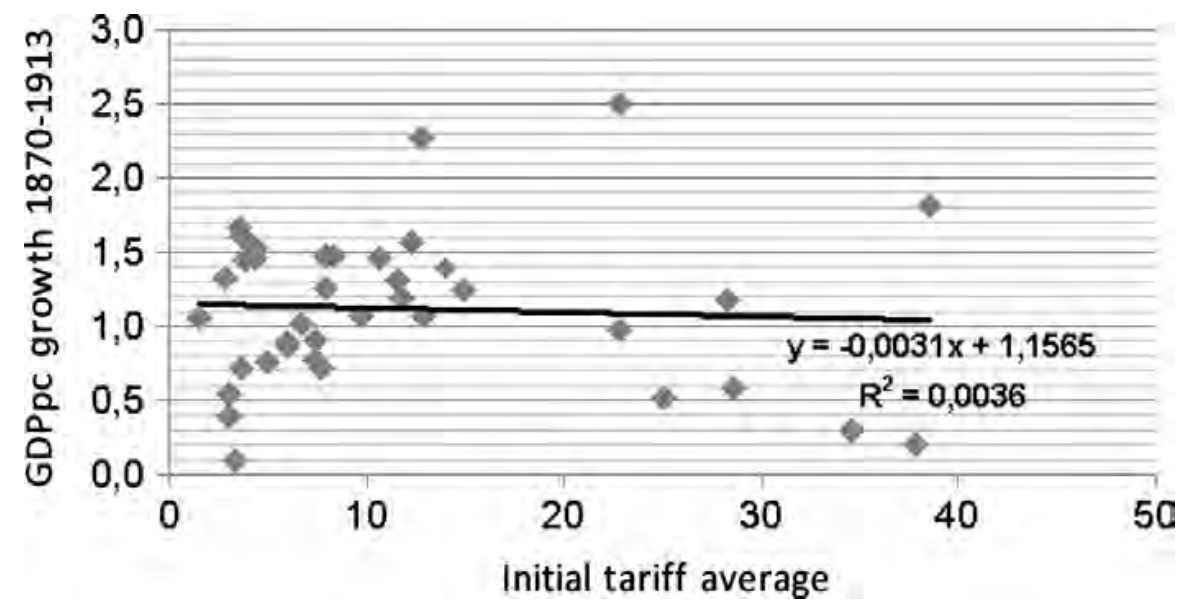

Figure 4. Association between initial tariff average and GDP $p c$ growth, I870-1913: worldwide

Source: $75 \mathrm{NT}$ and $70{ }_{3}$ GDPGR in Appendix, Table A2.

This may be an important issue for most Asian and African countries with the status of colony or protectorate in the late nineteenth century. ${ }^{\text {II }}$

II There is no doubt that for the late nineteenth century, political autonomy and independence need to be more accurately defined. For instance, Commonwealth countries such as Canada, Australia and New Zealand did not have commercial independene from the metropolis, but they developed an autonomous commercial policy 


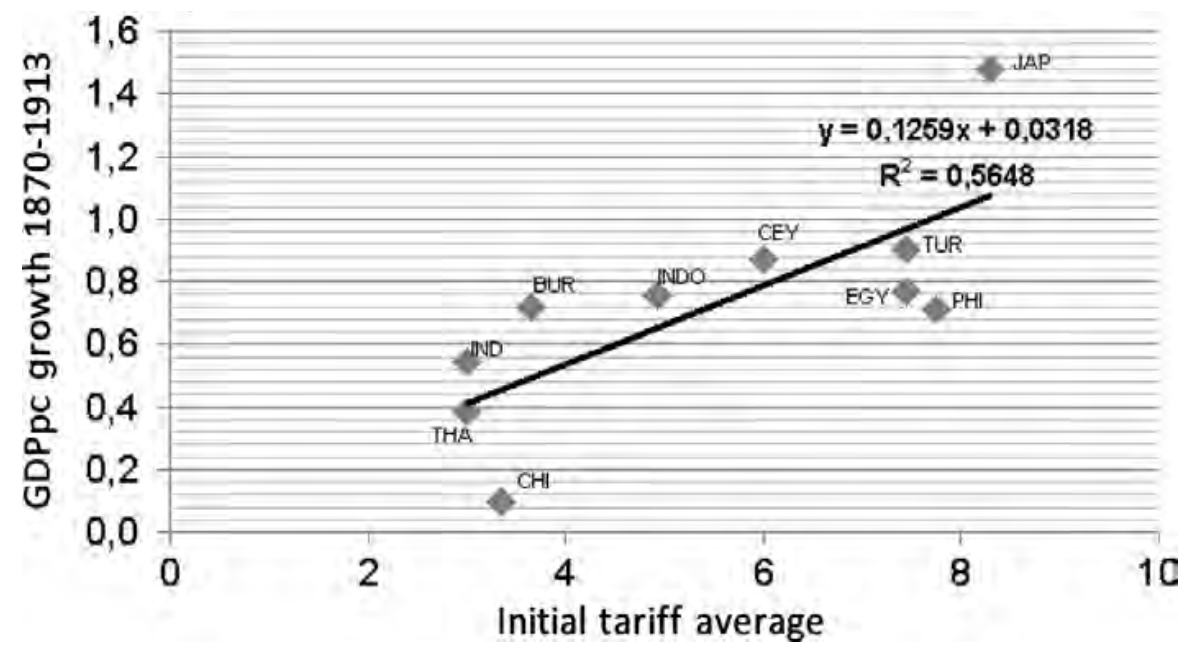

Figure 5. Association between initial tariff average and GDP pc growth, 1870-1913: poor countries and dependent trade policies (Asian and African colonies and protectorates)

Source: Initial tariff (75NT) and GDP growth (7013GDPGR) in Appendix, Table A2.

Figure 5 shows a stronger positive association between tariffs and growth for poor non-independent countries. These Asian and African countries had a low average tariff level (between 3 and 8 per cent) because their tariff policies enjoyed very limited independence from the core European metropolis. This exogenous determination of their commercial policy made it possible to control local pressure groups that wanted higher tariffs and led to a more neutral incidence of tariffs on the assignment of resources. ${ }^{\text {I2 }}$

By contrast, Figure 6 shows that for peripheral independent countries the relationship between tariff average and growth appears consistently negative. Politically independent poor countries had commercial policies designed by their own governments and parliaments. The European periphery and Latin America had high tariffs, especially for traditional industrial products without comparative advantage, even if some of them were linked with technologies developed from the First Industrial Revolution. From the second half of the nineteenth century many poor independent countries developed some low-skill manufactures, such as traditional textile and metal, imposing high tariffs especially in non-competitive sectors. Even if they reduced some manufacture tariffs, during the liberalization period around

for most of the period. Here we follow Clemens and Williamson (200I) and Williamson (2006a).

I2 For a similar approximation for the African and Asian colonies, see Williamson (2006a) and Bairoch (1989, 1996). 


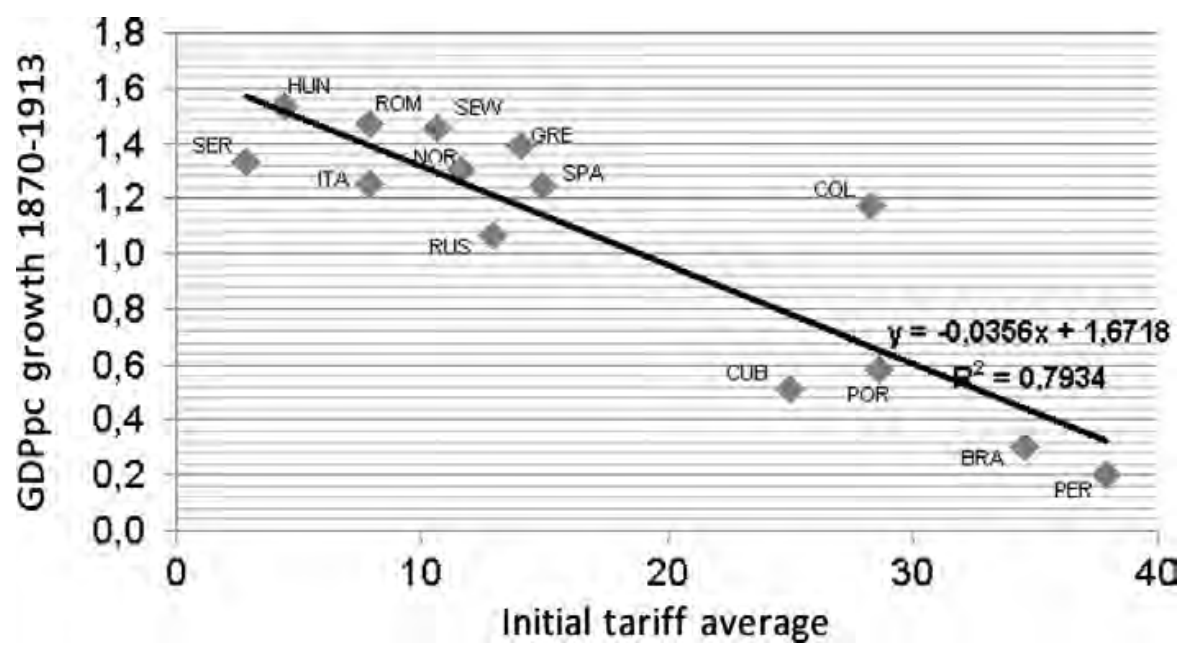

Figure 6. Association between initial tariff average and GDP pc growth, 1870-1913: poor countries with independent trade policies (European periphery and Latin America)

Source: Initial tariff $(75 \mathrm{NT})$ and GDP growth (7013GDPGR) in Appendix, Table A2.

the I850s and I860s, at the beginning of I870s they still had a level of manufacture protection that was more than threefold that of the European rich countries. During this period they developed well-established and organized lobbies which demanded high tariffs to defend national industry from the competition of rich countries' manufactured exports. When protectionism became fashionable again in I880 and I89os, peripheral governments were too weak to stop rent-seeking in the economy and most of them increased manufacture tariffs in non-competitive sectors. These results could reflect both the existence of poor underlying institutions, and a negative association between protected industrial sectors and long-run growth. ${ }^{13}$

\section{The causal mechanism between tariffs and growth: tariff structure and institutions}

In order for tariffs to have a positive effect on growth it is necessary that over time protected manufacturing sectors increase productivity more rapidly than less protected sectors because productivity growth should

${ }^{13}$ The average of the unweighted manufacture tariff for rich European and poor independent countries in 1875 was 7, 6 and 24, 4, respectively. See Appendix, Table A2. For an extensive discussion on Latin American protectionism, see Coatsworth and Williamson (2004) and Bértola and Williamson (2006). For the European periphery, see Federico and Tena (I998, I999) and Tena (I999, 2006). 
overcome the accumulated protection welfare losses. As Rodriguez and Rodrik (2000, p. 264) highlight: 'Such models are in fact formalizations of some very old arguments about infant industries and about the need for temporary protection to catch up with more advanced countries.' In this case the emphasis is on the dynamics of economies of scale, learningby-doing and technical innovation that protected sectors can develop as a consequence of temporal protection. However, it is questionable to assume that, without further qualifications, late nineteenth-century manufacturing as an undifferentiated sector responded to the criteria above. In this sense, a more reasonable assumption that we can make is that a country which focuses protection on highly skilled manufacturing industries will probably have higher rates of growth than if protection were focused on low-skilled manufacturing sectors.

This opens the question of how decisions about protecting low- or highskilled sectors were taken. The literature on endogenous protection has long recognized that a country's tariffs are an outcome of a political rentseeking game mainly determined by the type of institutions developed in the country (Krueger 1974, I997; Magee, Brock and Young 1989; Trefler I993; Grossman and Helpman I99I, I994; and Magee 2002). In fact, we can observe that countries or governments fall prey to 'rent seekers' and usually protect sectors because they are more interested in barring foreign competitors than promoting growth.

In a very recent paper Nunn and Trefler (2006), following Grossman and Helpman's (1994) protection-for-sale model, develop a new approach to examine the causal mechanism between tariffs and long-term growth for the late twentieth century, introducing externalities into the model. ${ }^{14}$ In the new model, tariffs affect future growth via externalities and these externalities vary across industries. High tariffs reduce welfare, and probably growth, if they are not distributed in favour of industries which generate positive externalities at an economy-wide level. Nunn and Trefler's contribution links to the previous literature on the institutions-protection dynamic, by suggesting that only countries with developed institutions, able to put a lid on lobbying, will favour tariffs in skill-intensive industries against non-skill-intensive industries. So, this model assumes that good institutions encourage politicians to be closer to pro-growth policies. ${ }^{15}$

Following Nunn and Trefler, this article adopts the hypothesis that a country with 'good' institutions will provide higher tariffs in industries that generate positive externalities. These externalities would have to operate at

${ }^{14}$ For the positive externalities of some sectors on general productivity, see Antweiler and Trefler (2002), Irwin (1994).

15 There are many Olsonian 'collective action' arguments and national case studies to support this argument; see Irwin and Klenow (1994), Magee, Brock and Young (1989), Federico and Tena (1999) and Tena (2005). 
an economy-wide level, coming from general economic and/or technological sources, rather than from manufacturing alone.

Following the tradition of the tariff-growth literature, and especially Nunn and Trefler (2006), equation (I) expresses the dependent relationship between the annual average rate of growth of GDP per capita and, as explanatory variables, tariff average, manufacture tariffs, tariff structure and the quality of institutions:

$$
\ln \mathrm{Y}_{\mathrm{CI}} / \mathrm{Y}_{\mathrm{Co}}=\beta_{\circ} \mathrm{Y}_{\mathrm{Co}}+\beta_{\mathrm{E}} \mathrm{E} \tau_{\mathrm{co}}+\beta_{\mathrm{SB}} \mathrm{SBv} \tau_{\mathrm{co}}+\mathrm{X}_{\mathrm{co}} \beta \mathrm{X}+\operatorname{RegDum}+\varepsilon_{\mathrm{c}}
$$

In this equation we consider only long-term growth, so we take $\mathrm{t}=\mathrm{O}$ to be the initial year (I870) and $t=I$, the final year (I9I3).

The dependent variable is $\ln \mathrm{Y}_{\mathrm{CI}_{\mathrm{I}}} / \mathrm{Y}_{\mathrm{Co}}$ (measured as the accumulated real GDP per capita growth rate). $\beta_{\circ} \mathrm{Y}_{\mathrm{Co}}$ refers to the initial GDP per capita in I870 used as the classical variable of control for convergence in this type of exercise. $\mathrm{E} \tau_{\mathrm{co}}$ is the tariff total or manufacture average (we will use both) in country $\mathrm{c}$ and initial year $\mathrm{O}$ (1875). Let $\mathrm{SBv} \tau_{\mathrm{co}}$ be the tariff structure showed by the skill-bias of tariffs in country $\mathrm{c}$ in initial year $\mathrm{O}$ (I875), and $\mathrm{X}_{\mathrm{co}} \beta \mathrm{X}$ as country-specific variables related to the quality of institutions. We also introduce regional dummies as regional fixed effect related to the level of development, land abundance or political independence, with only two values $O$ and $I$.

In the case of the initial tariff average $\left(\mathrm{E} \tau_{\mathrm{co}}\right)$ we will use the weighted total tariff average ' $75 \mathrm{NT}$ ' and the unweighted tariff average for manufacture '75UNTMAN', as presented in Table A2 in the Appendix. For the initial tariff structure $\left(\mathrm{SBv} \tau_{\mathrm{co}}\right)$ we will use the initial manufacture skill bias constructed following Nunn and Trefler's (2006) procedures. The first proxy used is presented as '75Corr-Skill', and defined as the cross-industry correlation between skill-intensity ranking estimated for 1875, shown in Table I, and the respective ranking of ad valorem tariffs of the same sectors. Most of the countries in our sample have a negative correlation sign between the skill and tariff ranking, showing in general that tariffs are usually higher in non-skill-intensive industries and lower in skill-intensive industries (see correlation in Table $\mathrm{A}_{3}$ in the Appendix). The second proxy used is ' 75 DiffSkill', which is constructed choosing an arbitrary 'cut-off' in the ranking of skill-intensive industries and calculated as the simple difference between the unweighted tariff average of the sectors situated in the 'up cut-off' and those of the 'down cut-off' for every country. This cut-off has been chosen in relation to the largest differences in the skill-intensity sectors around the mid point of the ranking (see Table I below). For the institutional variables, two types of index have been used: one that relates to the level of democracy of a country, POLITY2 (numeric), range $=-\mathrm{IO}$ to $\mathrm{IO}(-\mathrm{IO}=$ high autocracy; IO =high democracy); and another which measures the grade of 
Table I. Skill-intensity ranking

\begin{tabular}{clll}
\hline \hline Ranking & Description & Skill intensity & \\
\hline I & Ships & I3,0I & \\
2 & Machinery hardware etc. & I2,65 & \\
3 & Paper manufactures & I I,65 & \\
4 & Silk thrown & I I,58 & \\
5 & Iron steel manufactures & I I,29 & high cut-off \\
6 & Leather and manufactures & II,00 & \\
7 & Copper lingots, cakes, slabs & I0,0I & \\
8 & Alkali chemical products & 9,64 & low cut off \\
9 & Apparel & 9,27 & \\
I0 & Woollen \& worsted manufactures & 7,9 & \\
I I & Linen manufactures & 7,8 & \\
I2 & Cotton manufactures & 7,74 & \\
I3 & Jute canvas and sacking & 7,04 & \\
I4 & Woollen yarns(stuffs all wool) & 6,2 & \\
I5 & Linen yarn & 5,9 & \\
I6 & Cotton yarns undyed & 5,8 & \\
\hline \hline
\end{tabular}

Sources: The wages used to construct this 'skill-intensity' ranking came from two different sources: the wage distribution for male production workers in 12 manufacturing industrial sectors in 1890 in Iowa (covering the 165 largest cities) offered by Claudia Goldin and Frank Katz (1999, appendix table I, p. 46) and the patchy but abundant information on wage distribution in the textile sector (cotton, wool, hemp, jute and silk) in Barcelona in I884 (included in Scheuch I885).

independence of the executive government, XCONST (numeric). The last institutional variable would be used as proxy variable of good institutions in relation to the independence of the government from pressure groups.

\section{New data on industrial tariffs, skill-bias and institutions}

With the exception of Bairoch (I989), there are no comparative studies of industrial tariff levels of the I870s by country. Bairoch (I989) includes a table of comparative industrial tariff averages in 1875 for I 4 countries ('Author's computation based on tariff duties and prices for 14 different manufactured products', p. 42). But he does not offer information on the manufactured items included, or the method used (tariffs, prices and weights). A more accurate attempt at estimating manufacture tariffs by country was developed very recently in Lehman and O'Rourke (2008). This work offers a time-series estimation for the years I875-I9I3 of weighted agricultural, manufacturing and 'exotics' tariffs for the same sample of ro countries used in O'Rourke (2000). The procedure adopted was to divide customs revenues by total 
imports in 16 identical commodity categories for every country and classified as belonging to either. ${ }^{16}$

The estimation presented here has been devised adopting the following procedure (for details of the estimation of the industrial tariff database see Appendix). In the first place, British sources offered the ad valorem tariffs of 26 industrial products in 1875 for 32 countries; secondly, those 26 industrial products have been assembled in 16 industrial sectors for which their relative skill intensity has been estimated, based on the general structure of USA industrial wages in 1890 (using secondary sources) and other sources of textile wages in 1885 in Spain (from the USA Consular Reports).

The ad valorem tariff sources used in this estimation were taken, firstly, from the study directed by Robert Giffen and presented to the House of Commons in I 877 and I88I. The data were developed by the UK Statistical and Commercial Department Board of Trade, with the title: 'Import duties on British goods (foreign countries) and rates of duty (foreign and colonial) on British manufactures or produce'. Secondly, data came from the Annual Statement of Trade (I876) and Board of Trade (I878). The first work relates tariffs and prices imposed upon I5-24 manufactured articles in 32 countries; the second relates prices and duties for an additional 9 manufactured articles obtained from a similar group of countries. This material provides us with a complete series of homogeneous data of the tariff average for around 26 industrial products in 32 countries (for sources, products and technique used see Appendix).

A detailed study has been developed also for the classification of the mentioned manufacture tariffs in a ranking according to their respective skill intensity. In the literature, relative skill intensity by sector is estimated by using ratios of workers with more than 12 years of schooling over the total. To our knowledge, no data of this kind is available on the ratios of skilled workers in different industrial sectors at the end of the nineteenth century. ${ }^{17}$ Skill-intensity measures are apparently quite resistant to temporal and geographical change; we have made the assumption that capital is uniformly distributed between sectors, and in consequence that sectors with

I6 The authors do not make explicit how many of these identical I6 categories are manufactures. Apparently they get a weighted manufacture tariff average by dividing customs revenues by imports for the total category for every country. The estimation of the unweighted tariff average is not possible under this procedure. As elasticity of import demand for manufactures used to be quite high, weighted tariff averages undervalued the manufacture tariff average of countries and years with higher tariffs.

${ }_{17}$ The oldest compelling available source is the UK census of I95I, which offers figures for skilled, semi-skilled and unskilled blue-collar (male and female) and the number of white-collar workers by sectors. See the recent paper by Beltran, Ferry and Pons (2007), which includes an estimation of skill intensity based on this data. 
relatively higher salaries have a higher proportion of skilled workers. ${ }^{18}$ This means that we assume that higher 'median' wage sectors will rank higher in our estimations of skill intensity. ${ }^{19}$

The wages used to construct the skill-intensity ranking shown in Table I came from two different sources (as noted at the foot of the table). In the first case, the complete wage structure makes it possible to estimate the 'median' wage of the sector. In the second case, extensive but incomplete information on wages for different textile sectors allows us to construct incomplete professional samples by sector, but it suggests the use of a simple wage average instead of the 'median' average for the estimation skill-intensity ranking of the different textiles sectors.

For the institutional variables, the level of democracy of a country, POLITY 2 and the level of independence of the executive government, XCONST, the data came from the Polity IV database. It contains coded annual information on regime and authority characteristics for all independent states (with a total population greater than 500,000) in the global state system and covers the years $1800-2004 .^{20}$

\section{Evidence on tariffs and growth}

The recent paper by Lehmann and O'Rourke (2008) mentioned above uses panel data exploiting the variation in agricultural and industrial tariffs for a sample of Io countries, most of them rich, in the late nineteenth century. Attention is focused on the association of manufacture and agricultural tariff structure with the ups and downs of economic activity of the rich countries. ${ }^{2 I}$ The work developed here places greater emphasis on the manufacture tariff structure and long-run growth of rich and poor countries according to the skill-intensity structure of their manufacturing sector. Therefore we designed an extended and homogeneous ad valorem tariff database for around 26 industrial products for 32 countries in 1875 , and later we assembled these data in 16 industrial sectors, ranked according to their relative skillintensity bias. This model, for the first time, privileges the industrial tariff structure, the geographical coverage of data, and the long-run relationship

I8 This may produce errors in some circumstances because the temporal scarcity of some skills may offer high salaries independently of productivity. For this reason we prefer our broader measure of skill intensity represented by 75 Diff-Skill.

I9 Nunn and Trefler (2006) show how the use of alternative skill-intensity rankings at the same time as those of the USA (1972), South Africa (1997) and Brazil (I972) had no effect at all on the final results of their correlation coefficient between skill intensity and growth.

${ }^{20}$ See description of variables in POLITY IV Project.

${ }^{21}$ This is clearly noted in Lehmann and O'Rourke's (2008) conclusion: 'By focusing on five-year periods, in common with much of the empirical literature, we may have been picking up the short to medium run impact of protection, rather than the longer run effects' (p. I4). 
between tariffs and growth. In order to capture this effect, regional dummy fixed variables or different clubs of countries will be employed alternatively. The econometric strategy of this article is to run a simple cross-section model with interaction terms and fixed regional effects in order to capture the income and regional influence in the association between tariffs and long-run growth. ${ }^{22}$ Furthermore, an intuitive theoretical model of endogenous growth is provided which relates both sides of the equation. We expect that, in general terms, most of the countries of our sample will impose high tariffs in industries that generate no positive externalities and slow growth. In a cross-section study like this, the reduced number of observations allows the simultaneous introduction of several control variables and explanatory variables all together in a single regression equation. Average tariff $(75 \mathrm{NT})$, manufacture tariffs (75UNTMAN) and structure of protection (75Diff Skill) may not be put in one regression because there is a high correlation between them. Only the initial GDP per capita (70GDPpc) and the variables that proxy good institutions (75XCONST) would be used, in the same regression, with the regional dummies, as control variables. ${ }^{23}$

Table 2 tests the comparative explanatory power of the total tariff average, manufacture tariff and skill industrial tariff respectively for long-run growth in $1870-1913 .{ }^{24}$ Variables are not logged and the respective regressions include three additional dummy variables with regional fixed effects related to the level of development, land abundance or political independence (with only two values $O$ and $\mathrm{I}$, rich countries $=\mathrm{I}$, the rest $=0$; rich land-abundant countries $=\mathrm{I}$, the rest $=0$; politically independent countries $=\mathrm{I}$, the rest $=$ o) following the discussion in previous sections regarding the importance of the level of development, factor endowment and political independence variables in the explanation of regional asymmetry found between tariffs and growth by the literature. Regression I shows that these regional fixed effects are relevant in the regressions between the tariff average and late nineteenthcentury growth. The regional fixed-effect dummies allow extending the explanatory power of the initial average tariff on growth from the small group of rich countries, as defined by O'Rourke, to a more representative world of 38 countries. Furthermore, the results would show that in a larger

${ }^{22}$ Cross-sectional regression with initial measures of export of natural resources, openness, tariffs explaining long-run growth are common in this literature. See well-known empirical growth studies, such as Sachs and Warner (1999), Edwards (I992, I998) or Irwin (2002b).

23 The explanation why we have not shown one regression containing all variables is related to the high bivariate correlation coefficients between most variables shown in Table $\mathrm{A}_{3}$ of the Appendix. An exception to this high correlation is the low coefficient shown between $75 x$ Const and 75Diff-Skill.

24 The basic variables and sources of Table 2 are defined and commented on in Appendix Table A2 and Section 4. 
Table 2. Tariff structure and economic growth with regional fixed effects

\begin{tabular}{|c|c|c|c|c|c|}
\hline \multicolumn{6}{|c|}{ Dependent variable: growth in real per capita GDP, 1870 to 1913} \\
\hline & I & 2 & 3 & 4 & 5 \\
\hline $\begin{array}{l}\text { Initial per capita GDP } \\
\text { (70 GDPpc) }\end{array}$ & $\begin{array}{l}-0.0004 \\
0.005^{* * *}\end{array}$ & $\begin{array}{l}-0.005 \\
\underline{0.001}^{* * *}\end{array}$ & $\begin{array}{l}-0.005 \\
0.001^{* * *}\end{array}$ & $\begin{array}{l}-0.006 \\
0.001^{* * *}\end{array}$ & $\begin{array}{l}-0.005 \\
0.005^{* * *}\end{array}$ \\
\hline $\begin{array}{l}\text { Initial total tariff average } \\
\quad(75 \mathrm{NT})\end{array}$ & $\begin{array}{l}-\overline{0.023} \\
0.005^{* * *}\end{array}$ & & & & \\
\hline $\begin{array}{l}\text { Initial manufacture tariff } \\
\text { average unweighted } \\
\text { (75 UNTMAN) }\end{array}$ & & $\begin{array}{l}-\mathrm{I} .526 \\
\underline{0.013^{* *}}\end{array}$ & & & \\
\hline $\begin{array}{l}\text { Initial tariff skill bias } \\
\text { (75 Diff Skill) }\end{array}$ & & & 2.033 & $\begin{array}{l}2.039 \\
0.003^{* * *}\end{array}$ & \\
\hline $\begin{array}{l}\text { Goods institutions } \\
\text { (75XCONS) }\end{array}$ & & & & $\begin{array}{l}0.046 \\
0.225\end{array}$ & $\begin{array}{l}0.099 \\
0.013^{* *}\end{array}$ \\
\hline $\begin{array}{l}\text { Dummy abundant land } \\
\text { (DumLand) }\end{array}$ & $\begin{array}{l}0.663 \\
0.008^{* * *}\end{array}$ & $\begin{array}{l}0.621 \\
0.006^{* * *}\end{array}$ & $\begin{array}{l}0.574 \\
0.008^{* * *}\end{array}$ & $\begin{array}{l}\overline{0.575} \\
0.010^{* * *}\end{array}$ & $\begin{array}{l}0.356 \\
0.119\end{array}$ \\
\hline $\begin{array}{l}\text { Dummy rich } \\
\text { (DumRich) }\end{array}$ & $\begin{array}{l}\overline{0.542} \\
0.039^{* *}\end{array}$ & $\begin{array}{l}\overline{0.727} \\
0.001^{* * *}\end{array}$ & $\begin{array}{l}\overline{0.684} \\
0.002^{* * *}\end{array}$ & $\begin{array}{l}0.723 \\
0.007^{* * *}\end{array}$ & $\begin{array}{l}0.674 \\
0.009^{* * *}\end{array}$ \\
\hline $\begin{array}{l}\text { Dummy political } \\
\text { independence }\end{array}$ & $\begin{array}{l}0.793 \\
0.000^{* * *}\end{array}$ & $\begin{array}{l}\overline{0.848} \\
0.000^{* * *}\end{array}$ & $\begin{array}{l}\overline{0.954} \\
0.000^{* * *}\end{array}$ & $\begin{array}{l}0.83 \\
0.004^{* * *}\end{array}$ & $\begin{array}{l}0.479 \\
0.05 I^{*}\end{array}$ \\
\hline Number of observations & 38 & & 32 & 28 & 32 \\
\hline & & & & 0.675 & 0.503 \\
\hline $\mathrm{R}^{2}$ (Adjusted) & 0.489 & 0.556 & 0.608 & 0.582 & 0.407 \\
\hline
\end{tabular}

Note: P-values underlined.

*** significant at I $\%$; ${ }^{* *}$ significant at $5 \%$; significant at IO\%.

Sources: Appendix, Table A2.

world, with rich and poor countries included in the sample, the sign of this relationship changes from positive to negative. What is more important, as regression 2 shows, the countries which imposed higher tariffs on the manufacturing sector were those that had the worst growth performance, and this relationship is stronger than shown by the total tariff average. Exploring further the association between manufacture tariffs and growth, regression 3 offers some evidence to support the idea that there is a positive relationship between the efficiency of the structure of manufacture protection and growth. The efficiency of the structure of protection in this work means higher tariffs in the more skill-intensive manufacturing sectors, and it is measured by the initial tariff skill bias (our variable 75Diff Skill). The coefficient of correlation between manufacture tariffs (75UNTMAN) and tariff skill bias (75Diff Skill) is very high and negative ( $-0.9 \mathrm{I})$, which does not allow us to include both variables in the same regression, but would support the idea that those with higher manufacture tariffs were those with the most inefficient structure of manufacture protection. That would suggest too that countries which apparently put more emphasis on an import-substituting strategy, and imposed higher tariffs on manufacturing sectors, were those that had a more inefficient manufacture tariff structure and a worse growth 
performance. This evidence would fit with the initial hypothesis that more protected countries were more interested in barring foreign competitors than in promoting growth, which is consistent with the suggestion that tariffs may be the outcome of a political rent-seeking game in which the quality of institutions may play an important role as a causal variable. Nevertheless, we should decide between good tariff structure and good institutions, as the main factor responsible for good growth performance, because of the potential endogenous connection between both variables. Our concern is to find a direct connection between a good manufacture tariff structure and its potential positive externalities in the wide economy as the main explanatory variable for growth. Regression 5 in Table 2 shows, on one hand, that the coefficient of 'good institutions', explained by a variable as the level of independence of the executive government ( $75 \mathrm{XCONST}$ ), is very low but positive and significant. On the other hand, regression 4 offers a combination of both variables, good institutions and good tariff structure, in the same regression. The result shows that tariff structure and not institutions is the main variable explaining late nineteenth-century growth, which is consistent with the argument outlined above. ${ }^{25}$

Tables 3 to 6 present a test of the regional asymmetry of the different explanatory variables used above (total tariffs, manufacture unweighted tariffs, skill-bias tariff and good institutions). The econometric strategy

Table 3. Initial total tariffs and growth regressions with interaction terms

\begin{tabular}{|c|c|c|c|c|}
\hline \multicolumn{5}{|c|}{ Dependent variable: 1870-1913 GDP per capita growth } \\
\hline \multirow[b]{2}{*}{ Variables } & \multicolumn{2}{|c|}{ Eq. I } & \multicolumn{2}{|c|}{ Eq. 2} \\
\hline & Coeff. & Prob. & Coeff. & Prob. \\
\hline Constant & I.I2I & 0.000 & I.557 & $0.000^{* * *}$ \\
\hline Initial per capita GDP (70GDPpc) & 0.000 & 0.948 & 0.000 & 0.265 \\
\hline $75 \mathrm{NT} *$ Dummy RI & - & - & 0.023 & $0.017^{* *}$ \\
\hline 75NT*Dummy $\mathrm{R}_{2}$ & - & - & $0.02 \mathrm{I}$ & $0.005^{* * *}$ \\
\hline${ }_{75} \mathrm{NT}^{*}$ Dummy $\mathrm{R}_{3}$ & - & - & -0.024 & $0.042^{* *}$ \\
\hline 75NT*Dummy R4 & - & - & -0.100 & $0.020^{* *}$ \\
\hline $75 \mathrm{NT}^{*}$ Dummy rich $\left(\mathrm{R}_{\mathrm{I}}+\mathrm{R}_{2}\right)$ & 0.024 & $0,035^{* *}$ & - & - \\
\hline $75 \mathrm{NT}^{*}$ Dummy poor $\left(\mathrm{R}_{3}+\mathrm{R}_{4}\right)$ & -0.015 & $0,08 I^{*}$ & - & - \\
\hline $\begin{array}{l}\text { Number of observations } \\
\text { Prob > F }\end{array}$ & \multicolumn{2}{|c|}{$\begin{array}{l}37 \\
0.00^{* * *}\end{array}$} & \multicolumn{2}{|c|}{$\begin{array}{l}37 \\
0.00^{* * *}\end{array}$} \\
\hline R-squared & \multicolumn{2}{|c|}{0.42} & \multicolumn{2}{|c|}{0.44} \\
\hline Adj R-squared & \multicolumn{2}{|c|}{0.32} & \multicolumn{2}{|c|}{0.33} \\
\hline
\end{tabular}

Sources: Appendix, Table A2.

${ }^{25}$ That would be possible because the coefficient of correlation between the skill bias (75diff Skill) and our measures of good institutions (75XCONST) and (75POLT2) are very low, around 0,20 and 0,08 respectively. 
Table 4. Initial manufacture unweighted tariffs and growth regressions with interaction terms

\begin{tabular}{|c|c|c|c|c|}
\hline \multicolumn{5}{|c|}{ Dependent variable: 1870-1913 GDP per capita growth } \\
\hline \multirow[b]{2}{*}{ Variables } & \multicolumn{2}{|c|}{ Eq. I } & \multicolumn{2}{|c|}{ Eq. 2} \\
\hline & Coeff. & Prob. & Coeff. & Prob. \\
\hline Constant & I.I82 & 0.000 & I.824 & 0.000 \\
\hline $\begin{array}{l}\text { Initial per capita GDP } \\
\text { (70GDPpc) }\end{array}$ & 0.000 & 0.980 & 0.000 & $0.077^{*}$ \\
\hline 75UNTMAN*Dummy RI & - & - & 0.008 & $0.00 I^{* * *}$ \\
\hline 75UNTMAN*Dummy R2 & - & - & 0.018 & $0.000^{* * *}$ \\
\hline 75UNTMAN*Dummy $\mathrm{R}_{3}$ & - & - & -0.022 & $0.004^{* * *}$ \\
\hline 75UNTMAN*Dummy R4 & - & - & -0.107 & $0.002^{* * *}$ \\
\hline $\begin{array}{l}\text { 75UNTMAN*Dummy rich } \\
(\mathrm{R} I+\mathrm{R} 2)\end{array}$ & 0.022 & $0,0698^{*}$ & - & - \\
\hline $\begin{array}{l}\text { 75UNTMAN*Dummy poor } \\
\left(\mathrm{R}_{3}+\mathrm{R}_{4}\right)\end{array}$ & -0.012 & $0,0 \mathrm{I} 8^{* *}$ & - & - \\
\hline Number of observations & \multirow{2}{*}{\multicolumn{2}{|c|}{$\begin{array}{l}33 \\
0.00^{* * *}\end{array}$}} & \multirow{2}{*}{\multicolumn{2}{|c|}{$\begin{array}{l}33 \\
0.00^{* * *}\end{array}$}} \\
\hline Prob $>F$ & & & & \\
\hline R-squared & \multicolumn{2}{|c|}{0.38} & \multicolumn{2}{|c|}{0.53} \\
\hline Adj R-squared & \multicolumn{2}{|c|}{$0.3 \mathrm{I}$} & \multicolumn{2}{|c|}{0.44} \\
\hline
\end{tabular}

Table 5. Initial skill-bias tariffs and growth regressions with interaction terms

\begin{tabular}{|c|c|c|c|c|}
\hline \multicolumn{5}{|c|}{ "Dependent variable: 1870-I913 GDP per capita growth } \\
\hline \multirow[b]{2}{*}{ Variables } & \multicolumn{2}{|c|}{ Eq. I } & \multicolumn{2}{|c|}{ Eq. 2} \\
\hline & Coeff. & Prob. & Coeff. & Prob. \\
\hline Constant & I.039 & 0.000 & I.I5I & $0.000^{* * *}$ \\
\hline $\begin{array}{l}\text { Initial per capita GDP } \\
\quad(70 \mathrm{GDPpc})\end{array}$ & 0.000 & 0.392 & 0.000 & 0.645 \\
\hline 75DIFF_SKILL*Dummy RI & - & - & $-2.82 \mathrm{I}$ & 0.529 \\
\hline 75DIFF_SKILL*Dummy R2 & - & - & -3.172 & $0.046^{* *}$ \\
\hline 75DIFF_SKILL*Dummy $\mathrm{R}_{3}$ & - & - & I. 556 & $0.035^{* *}$ \\
\hline 75DIFF_SKILL*Dummy R4 & - & - & -16.408 & 0.188 \\
\hline $\begin{array}{l}\text { 75DIFF_SKILL*Dummy rich } \\
(\mathrm{R} 1+\mathrm{R} 2)\end{array}$ & -3.259 & $0,039^{* *}$ & - & - \\
\hline $\begin{array}{l}\text { 75DIFF_SKILL*Dummy } \\
\text { poor }\left(\mathrm{R}_{3}+\mathrm{R}_{4}\right)\end{array}$ & I.29I & $0,066^{*}$ & - & - \\
\hline Number of observations & \multirow{2}{*}{\multicolumn{2}{|c|}{$\begin{array}{l}32 \\
0.00^{* * *}\end{array}$}} & \multicolumn{2}{|c|}{32} \\
\hline Prob $>F$ & & & \multirow{2}{*}{\multicolumn{2}{|c|}{$0.015^{* *}$}} \\
\hline R-squared & \multicolumn{2}{|c|}{0.35} & \multirow{2}{*}{\multicolumn{2}{|c|}{$\begin{array}{l}0.40 \\
0.28\end{array}$}} \\
\hline Adj R-squared & \multicolumn{2}{|c|}{0.28} & & \\
\hline
\end{tabular}


Table 6. Initial skill-bias tariffs and growth regressions with interaction terms

\begin{tabular}{|c|c|c|c|c|}
\hline \multicolumn{5}{|c|}{ Dependent variable: 1870-1913 GDP per capita growth } \\
\hline \multirow[b]{2}{*}{ Variables } & \multicolumn{2}{|c|}{ Eq. I } & \multicolumn{2}{|c|}{ Eq. 2} \\
\hline & Coeff. & Prob. & Coeff. & Prob. \\
\hline Constant & I.597 & 0.000 & I.6II & 0.000 \\
\hline $\begin{array}{l}\text { Initial per capita GDP } \\
\quad(70 \mathrm{GDPpc})\end{array}$ & 0.000 & 0.314 & 0.000 & 0.332 \\
\hline 75DIFF_SKILL*Dummy RI & - & - & -2.213 & 0.603 \\
\hline 75DIFF_SKILL*Dummy R2 & - & - & $-2.73 \mathrm{I}$ & $0.073^{*}$ \\
\hline 75DIFF_SKILL*Dummy $\mathrm{R}_{3}$ & - & - & 2.269 & $0.003^{* * *}$ \\
\hline 75DIFF_SKILL*Dummy R4 & - & - & -9.223 & 0.587 \\
\hline $\begin{array}{l}\text { 75DIFF_SKILL*Dummy rich } \\
\left(\mathrm{RI}_{\mathrm{I}}+\mathrm{R} 2\right)\end{array}$ & -2.710 & $0,063^{*}$ & & \\
\hline $\begin{array}{l}\text { 75DIFF_SKILL*Dummy poor } \\
\left(\mathrm{R}_{3}+\mathrm{R}_{4}\right)\end{array}$ & 2.239 & $0,003^{* * *}$ & - & - \\
\hline $75 \mathrm{POLT}_{2}$ & 0.013 & $0.42 \mathrm{I}$ & 0.014 & 0.409 \\
\hline Number of observations & & \multicolumn{2}{|c|}{28} \\
\hline Prob $>F$ & & o**** & \multirow{2}{*}{\multicolumn{2}{|c|}{$0.02^{* *}$}} \\
\hline R-squared & \multicolumn{2}{|c|}{0.48} & \multirow{2}{*}{\multicolumn{2}{|c|}{$\begin{array}{l}0.49 \\
0.34\end{array}$}} \\
\hline Adj R-squared & \multicolumn{2}{|c|}{0.38} & & \\
\hline
\end{tabular}

Sources: Appendix, Table A2.

used in these tables was to introduce four different regional dummies, with interaction terms, for each of the respective independent variables. On one hand, in equation 2 we introduce our four different regional dummy variables: Dummy RI: rich European countries; Dummy R2: rich new settlers; Dummy R3: poor politically independent countries; and Dummy $\mathrm{R} 4$ : colonies and protectorates. On the other hand, in equation I we offer a regional division of the world between the 'rich club' (Dummy rich (RI+R2)) and the 'poor club' (Dummy poor $\left(\mathrm{R}_{3}+\mathrm{R}_{4}\right)$. As expected, following the main hypothesis of the article, results show how the relationship between tariffs and growth is only slightly positive and significant for the 'rich countries club' and negative and strongly significant for the rest. This happened for total and for manufacture tariffs (NT and UNTMAN respectively) and in both equations. In equation I, we present the world divided into two separate clubs according to the level of development (Dummy rich ( $\left.\mathrm{R} I+\mathrm{R}_{2}\right)$ and Dummy poor $\left(\mathrm{R}_{3}+\mathrm{R}_{4}\right)$ ), and in equation 2 the impact of every regional dummy. Results show a positive sign for the rich Europeans and landabundant countries (Dummy RI and Dummy R2) and a negative sign for the poor independent (Dummy $\mathrm{R}_{3}$ ) and for the poor dependent countries (Dummy R4) respectively. Therefore, in line with previous findings, Tables 3 and 4 show that the influence of tariff average and tariff manufacture on growth at the end of the nineteenth century was negative for the world 
globally, as Table 2 shows, but that the impact was different for rich and poor countries. It would confirm that Bairoch and O'Rourke's tariff-growth positive hypothesis apparently only works in the case of the 'rich countries club'.

Despite a general positive correlation between the protection of skillintensive sectors and growth applying to the entire sample, still regional asymmetry persists, as shown in Tables 5 and 6 . Results in Table 2 fit with the general expectations that countries that protected the more skilled industrial sectors were those with the best growth performance. However, regional correlations introduced in equation $\mathrm{I}$ of Tables 5 and 6 show that this mainly happened in the 'poor countries club'. On the contrary, rich countries appear to have a negative relationship between the efficiency of the structure of protection and growth performance, even if coefficients are significant only if the interval of confidence is reduced to 5 or even Io per cent. This appears to be as a paradox, as it means that, in the case of the rich countries, those that protected the unskilled manufacturing sectors more ended-up with better growth performance. However, at a deeper level of disaggregation, a negative correlation is only significant for the new settler land-abundant countries (Dummy R2), but not for the rich European countries (Dummy RI). To explain this result one can consider that new settler economies may be outliers because their special factor endowment created the conditions to impose high tariffs for reasons involving public finance and political economy, as discussed in the introduction. For these countries growth was exogenous to protection in general, while the structure of protection was oriented towards low-skilled sectors because their relative lower elasticity of demand led to maximization of tax revenues.

\section{Conclusions}

The potential dynamic relationship between tariffs and growth can be better appreciated in the long run, and this article highlights the importance of the structure of protection and regional asymmetry in this longterm relationship. In theory, there is no reason to find a systematically unambiguous association between average tariffs and growth in different groups of countries, and regional asymmetry may be partially explained by different tariff structures.

The article's main methodological innovation is the use of a new database of industrial tariffs for 32 countries in the I870s. This new evidence allows us, for the first time, to include manufacture protection and manufacture tariff structure as explanatory variables alongside tariff average, and different regional dummies. Results show that, at a global level, income, factor endowment, and political independence are important variables to explain regional asymmetry in the association between tariffs 
and growth. Under these conditions, an increase in protection, measured by total and manufacture tariff averages, implied more protection of unskilled and inefficient sectors and less growth, and this is especially consistent with the behaviour of poor countries in the late nineteenth century. Protection was apparently positive for the 'rich countries club', but had a limited impact on growth.

Comparative advantage in low-skilled sectors might be an engine for growth, therefore higher protection of those sectors might appear as a legitimate option. However, international trade theory and historical experience show that tariffs never focus on relatively low-cost sectors with comparative advantage in the present day. Tariffs in non-comparative advantage sectors in the present day may have a positive relationship with growth in the future, if high tariffs are imposed in sectors with dynamic positive externalities. Endogenous growth literature assumes that this might be the case if 'good institutions' succeed in controlling rent-seeking.

In this article tariff skill-bias runs through measures of good institutions, and reduces the possibility that the skill-bias of the protection structure is capturing the broader effect of 'good institutions' on growth. In broader terms, this article proves that the initial total and manufacture tariff negative relation with growth is related to the tariff structure, and shows how those that protected skill-intensive sectors had a better growth performance than those who did not, and this is specially true for the poor countries. Tariff structure provides a better causal mechanism for explaining the $1870-1913$ growth than the initial tariff average, independently of income level. The article also proves the strong regional asymmetric effect of tariffs on growth in the world between the rich and the poor.

This works thus rejects the established view that, as a general statement, tariffs were positively associated with long-run growth in late nineteenth century, as has been maintained recently by O'Rourke (2000), Williamson (200I, 2006a), Jacks (2006). European and Latin American peripheral countries demanded high tariffs to defend national industry from the competition of manufactured imports from rich countries. Tariff structure was the result of a rent-seeking policy competition between inefficient sectors trying to defend national manufactures more than a governmental tariff import-substitution strategy. An inefficient manufacture tariff structure did not foster positive externalities at an economy-wide level, and this was especially true for the developing world. That is probably the reason why total, and especially manufacture tariffs, usually appear associated with negative growth in the world in the late nineteenth century.

Protection, in general, seems negatively correlated with growth, but apparently had a slightly positive impact on the 'rich country club'. This result, in the strict sense, is consistent with Lehman and O'Rourke (2008), highlighting the fact that manufacture tariffs were positively related to growth 
in the developed world in the late nineteenth century: 'it could well be that what was true in our sample of more or less affluent economies was not true for poorer regions of the world as well' (p. I3). Strong regional asymmetries suggest that the association between protection and growth depends on what was protected. This article suggests that in the late nineteenth century, as today, it is necessary not only to look at the different impacts of agricultural vs industrial protection, but at the efficiency in the configuration of manufacture protection too. Much work is still to be done regarding the reasons for the different configurations of tariff structures, but also regarding the different impact of tariff policy in different economic contexts, to understand more about the dynamic mechanism of causality between tariffs and long-run growth.

\section{Acknowledgements}

Earlier versions of this paper were presented in 2007 at the Seminare Chaire de Finances Internacionales, Sciences Po, Paris; sixth European Historical Economics Society Conference, Lund 2007; sixth World Congress of Cliometrics, Dalkeith Palace, Edinburgh; LSE Thesis workshop in Economic History, London. Thanks to participants, especially to Marc Flandreau, Kevin O'Rourke and Knick Harley. Additional comments were made by Concha Beltran, Ma Angeles Pons, Leandro Prados de la Escosura and Jeffrey Williamson. Special thanks are due to Esteban Nicolini and Felipe Fernandes for their intellectual support and econometric advice, and to Paolo Di Martino for his comments and editing help. The Spanish Ministerio de Ciencia e Innovación, research projects ECO2008-02089 and NEINVECON, is gratefully acknowledged.

\section{References}

ANTWEILER, W. and TREFLER, D. (2002). Increasing returns and all that: a view from trade. American Economic Review, 92, pp. 93-II9.

BAIROCH, P. (1972). Free trade and European economic development in the I9th century. European Economic Review, 3, pp. 2 II -45.

BAIROCH, P. (I976). Commerce exteriour et development economique de l'Europe au XIX siècle. Paris and The Hague: Mouton.

BAIROCH, P. (I989). European trade policy, I8I5-I9I4. In P. Mathias and S. Pollard (eds.), The Cambridge Economic History of Europe, vol. VIII: The Industrial Economies: The Development of Economic and Social Policies. Cambridge: Cambridge University Press, pp. I-6o.

BAIROCH, P. (1996). Economics and World History. Brighton: Havester Wheatsheaf.

Beltran, C., FERri, J. and PONS, M. A. (2007. Wage inequality and globalisation: what can we learn from the past? A general equalibrium approach. FUNCAS Working Paper, no. 352. 
BOARD OF TRADE (I905). The comparative incidence of foreign and colonial import tariffs on the principal classes of manufactures exported from the United Kingdom. British Parliamentary Papers, LXXXIV, pp. 280-320.

BÉRTOLA, L. and Williamson, J. (2006). Globalization in Latin America before I940. In V. Bulmer-Thomas, J. Coatsworth and R. Cortés Conde (eds.), The Cambridge Economic History of Latin America, vol. II: The Long Twentieth Century. Cambridge: Cambridge University Press.

Clemens, M. A. and Williamson, J. G. (200I). A tariff growth paradox? Protection's impact on the world around 1875-1997. NBER Working Paper Series, 8459.

Clemens, M. A. and Williamson, J. G. (2004). Why did the tariff-growth correlation reverse after I950? Fournal of Economic Growth, 9(I), pp. 5-46.

CoATsworth, J. and Williamson, G. J. (2004). Always protectionist? Latin American tariffs from independence to Great Depression. Fournal of Latin American Studies, 36(2), pp. 205-32.

DE Long, B. (I995). Trade policy and American standard of living: a historical perspective. Mimeo: University California Berkeley, sixth draft.

DeJONG, D. and Ripoll, M. (2006). Tariffs and growth: an empirical exploration of contingent relationships. Review of Economics and Statistics, 88(4), pp. 62540.

EDWARDS, S. (I992). Trade orientation, distortions and growth in developing countries. Fournal of Development Economics. 39, pp. 3I-57.

EDWARDS, S. (I998). Openness, productivity and growth: what do we really know? Economic Fournal, I08, pp. 383-98.

FEDERICO, G. and TENA, A. (I99I). On the accuracy of international foreign trade statistics (I909-I935): Morgenstern revisited. Explorations in Economic History, 28 (3), pp. 259-73.

FEDERICO, G. and TENA, A. (I998). Was Italy a protectionist country? European Review of Economic History, 2(I), pp. 73-97.

FEDERICO, G. and TENA, A. (I999). Did trade policy foster Italian industrialization: evidence from the effective protection rates I870-I930. Research in Economic History, 19, pp. I I I-38.

Findlay, R. and O'Rourke, H. (2007). Power and Plenty. Trade, War, and the World Economy in the Second Millennium. Princeton and Oxford: Princeton University Press.

Goldin, C. and KaTz, L. F. (I999). The returns to skill in the United States across the twentieth century. NBER Working Papers, 7I26.

Grossmann, G. M. and HelPMAN, E. (I99I). Innovation and Growth in the Global Economy, Cambridge, MA: MIT Press.

Grossmann, G. M. and Helpman, E. (I994). Protection for sale. American Economic Review, 84(4), pp. 833-50.

Grossmann, G. M. and Helpman, E. (200I). Special Interest Politics. Cambridge, MA: MIT Press.

IRWIN, D. A. (200I). Tariffs and growth in late nineteenth century America. The World Economy, 24, pp. I5-30.

IRWIN, D. A. (2002a). Did import substitution promote growth in late nineteenth century. NBER Working Papers, W875I. 
IRWIN, D. A. (2002b). Interpreting the tariff-growth correlation in the late nineteenth century. American Economic Review (Papers E Proceedings) 92, pp. I65-9.

IRWIN, D. A. and KLENOW, P. J. (I994). Learning-by-doing spillovers in the semiconductor industry. Fournal of Political Economy, 102, pp. 1200-27.

IRWIN, D. A. and TERVIO, M. (2002c). Does trade raise income? Evidence from the twentieth century. Fournal of International Economics, 58, pp. I-I8.

JACKS, D. S. (2006). New results on the tariff-growth paradox. European Review of Economic History, Io, pp. 205-30.

KRUEGER, A. (I974). The political economy of the rent seeking society. American Economic Review, 64, pp. 29I-303.

KRUEGER, A. (I997). Trade policy and economic development: how we learn. American Economic Review, 87(I), pp. I-22.

LEAGUE of Nations (1927). Tariff Levels. Indices. Geneva, pp. I-38.

LEHMAN, S. H. and O'ROURKE, K. S. (2008). The structure of protection and growth in the late I9th century. NBER Working Papers, I4493.

LEWIS, W. A. (1978). Growth and Fluctuations, I870-I9I3. Boston: Allen and Unwin.

LIEPMAN, H. (I938). Tariff Levels and the Economic Unity of Europe. London: Allen and Unwin.

Maddison, A. (200I). The World Economy: A Millennial Perspective. Paris:

Development Centre of the Organization for Economic Co-operation and Development.

Maddison, A. (2003). The World Economy: Historical Statistics. Paris: Development Centre of the Organization for Economic Co-operation and Development.

MAGEE, C. (2002). Endogenous trade policy and lobby formation: an application to the free rider problem. Fournal of International Economics, 57(2), pp. 449-7I.

MAGEE, S., BROCK, W. and Young, L. (1989). Black Hole Tariffs and Endogenous Policy Theory: Political Economy in Equilibrium. New York: Cambridge University Press.

Milward, A. S. and Soul, S. B. (I977). The Development of the Economies of Continental Europe, I850-I9I4. London: George Allen and Unwin.

NunN, N. and Trefler, D. (2006). Putting the lid on lobbying: tariff structure and long-term growth when protection is for sale. NBER Working Papers, I2 I64.

O'Rourke, K. (1997a). The European grain invasion, I870-I913. Fournal of Economic History, 57, pp. 775-80I.

O'Rourke, K. (2000). Tariffs and growth in the late I9th century. Economic fournal, II0, pp. 456-83.

O'Rourke, K. and Williamson, J. G. (1999). Globalization and History. Cambridge, MA: MIT Press.

Polity IV PROJECT. Developed by Inter-University for Political and Social Research (ICPSR) and the University of Colorado and is housed at the Center for International Development and Conflict Management at the University of Maryland, College Park, www.cidcm.umd.edu/polity/

Pollard, S. (1982). Peaceful Conquest. Oxford: Oxford University Press.

RODRIGUEZ, F. and RODRIK, D. (2000). Trade policy and economic growth: a sceptic's guide to the cross-national evidence. NBER Macroeconomics Annual, I5, $26 \mathrm{I}-325$. 
Rodrik, D., SUbraniUm, A. and TREBI, F. (2002). Institutions rule: the primacy of institutions over geography and integration in economic development. CEPR Discussion Papers, 3643.

RouTH, G. (1985). Occupation and Pay in Great Britain 1906-1979, 2nd edn. London: Macmillan.

SACHS, J. D. and WARNER, A. M. (I999). The big rush, natural resource booms and growth. Fournal of Development Economics, 59(I), 43-76.

SCHEUCH, F. H. S. (1885). Labour in Europe, vol. 2: A Report from the US Consul in Spain in 1885 .

TENA-JUnguito, A. (1992). Las estadísticas históricas del comercio internacional (I890-1960): fiabilidad y comparabilidad (Estudios de Historia Económica, no. 24). Madrid: Banco de España.

TENA-Junguito, A. (I999, 2006). Un nuevo perfil del proteccionismo español durante la Restauración I875-1930. Revista de Historia Económica, I7(3), 579-62I. Translated as 'Spanish protectionism during the Restauración I875-1930' in J.-P. Dormois and P. Lains (eds.), Classical Trade Protectionism I815-1914: Fortress Europe. London and New York: Routledge (Explorations in Economic History), pp. 265-97.

TENA-JunguiTO, A. (2005). The good reputation of late XIX century protectionism: manufacture versus total protection in the European tariff growth debate. Paper presented to the 6th Conference of EHES, Istanbul, 9 September 2005.

TENA-Junguito, A. (2006). Assessing the protectionist intensity of tariffs in nineteenth-century European trade policy. In J.-P. Dormois and P. Lains (eds.), Classical Trade Protectionism I815-I9I4: Fortress Europe (Explorations in Economic History). London and New York, Routledge, pp. 99-I20.

TREFLER, D. (1993). Trade liberalization and the theory of endogenous protection: an econometric study of US import policy. Fournal of Political Economy, IoI(I), pp. $138-60$.

WILLIAMSON, J. (2006a). Explaining world tariffs I870-1938: Stolper-Samuelson, strategic tariffs and state revenues. In R. Findlay, R. Henriksson, H. Lindgren and M. Lundahl (eds.), Eli F. Heckscher, International Trade, and Economic History. Cambridge, MA: MIT Press.

WiLliamson, J. (2006b). Globalization, de-industrialization and underdevelopment in the third world before the modern era. Revista de Historia Económica. Fournal of Iberian and Latin American Economic History, I, pp. 9-36.

VAMVAKIDIS, A. (2002). How robust is the growth-openness connection?

Historical evidence. Fournal of Economic Growth, 7, pp. 57-80.

\section{Appendix: Estimation of the industrial tariff database in 1875}

There is some well-known contemporaneous estimation of comparative manufacture tariff averages by country before World War I. The League of Nations (1927) offers comparative index numbers for more than a dozen countries in 1913, but only Liepman (1938) develops a complete 
disaggregated study by sector with an explicit methodology for the same year. Another relevant study, less commonly used by economic historians, is that of the Board of Trade (1905), which offers estimations of tariff averages in 20 countries for 32 manufactured articles.

For I870s, there is not a single systematic study, so to develop the necessary quantitative variables on cross-country industrial sector tariffs, a new panel of data has been constructed on the ad valorem tariffs of 26 industrial articles in 1875 for 32 countries based on British sources. Following League of Nations and Liepman recommendations, we offer both the unweighted and the weighted tariff average. For the first, a simple arithmetic average of the 26 industrial articles has been estimated for every country, for the second, the relative importance of every article in total British exports is used as weight (see column 3 of Table Ar in this Appendix). This technique involves, in the first place, making a list of the principal classes of goods and assigning a rough 'weight' to each group according to its comparative importance in British exports. A few leading articles or classes of articles are then chosen from each group as representative of the whole group, and the average tariff rates of duty on these leading articles for each country are taken as fairly representative of the tariff treatment of the whole group. These tariffs should be expressed using the standard British monetary, capacity, mass or weight units for the corresponding articles (for special calculations see the technical specifications below points (a), (b) and (c) in Table AI).

The sources present the incidence of import tariffs on the principal manufactures exported from United Kingdom (the main world manufacture exporter in 1875) in more than 32 countries. This estimation uses British fob export prices instead of national cif import prices in the denominator for the estimation of the ad valorem tariffs. On the one hand, this would imply an over-bias, but in the case of manufactured articles with low freight factors, practical implementation of fob instead of cif prices makes little difference to the final results. ${ }^{26}$ On the other hand, especially for poor countries, British export values are in fact closer to real market prices than the low accurate import unit values that most of the poor countries had in their respective official trade statistics in $1870 .{ }^{27}$

To obtain the sector tariff average, the unweighted tariff of the articles belonging to the sector was used. In this way, a complete series of homogeneous data of the tariff average for $14-16$ industrial sectors in 32 countries

${ }^{26}$ The League of Nations (1927) used cif import and fob export prices for the estimation of total tariff average and concluded that 'the results obtained under the two systems are in fair accordance, but those from method B (fob export prices) tend to be slightly higher (on the average circa 8 per cent)', p. 6. In the case of the estimation of manufactures fob the accordance between the two systems is probably very close because manufacture freight factors are much lower than for primary products.

${ }^{27}$ For the accuracy of international foreign trade values see Federico and Tena (I99I) and Tena (1992). 
was obtained (for the sectors see Table I; for the countries see Table A2). This method (which is adopted below) has the advantage of applying a uniform standard to all countries, both as regards the list of articles on which the duties are calculated, and the relative 'weight' attached to each article. The unweighted manufacture tariff by country assumes an artificial standard import demand structure for every country which has not been biased by tariffs. ${ }^{28}$

\section{Sources}

Ad valorem rates, import duties and prices of manufactures exported in 1875

The data on prices were presented with the respective tariffs by the UK Statistical and Commercial Department Board of Trade, with the title 'Import duties on British goods (foreign countries) and rates of duty (foreign and colonial) on British manufactures or produce', and also on import duties in 'British goods (foreign countries) return of the estimated average ad valorem rate of import duty levied in the principal European countries and in the United States, on certain articles of British produce or manufacture', both in British Parliamentary Papers vol. LXXVI.I8I, session I877. This study has been complemented by other estimations on prices, especially for textiles (for instance, cotton manufactures and woollen and worsted manufactures) but also for an additional nine manufactured articles for the year I875, from the 'Annual statement of trade: return of the values of the exports of British and Irish produce I854-I880'. British Parliamentary Papers vol. LXV, session I882.

With this material a complete series of additional homogeneous data of the tariff average for $16-14$ industrial sectors in 32 countries has been obtained (for the final sector aggregation see Table AI). This study was directed by Robert Giffen and presented to the House of Commons in I877 and I88I.

Technical specification for some articles used for I875:

(a) In the same way as for cotton piece goods, for cotton yarns 40 yards to the $\mathrm{lb}$ has been assumed. See British Parliamentary Papers (I905), p. $29 \mathrm{I}$.

(b) Cotton piece goods are entered in UK Trade Accounts by the yard, whereas most duties are imposed by weight or graduated according to the weight per square metre of the tissues. An 'average account' of

28 The unweighted average was recommended by Loveday in his work on 'tariff levels' for the League of Nations (1927) and was also supported by Liepman (I938). The League of Nations (I927) estimated a tariff manufacture unweighted average using I IO manufactured articles (excluding semi-manufactures). Liepman (I938) used the unweighted average of tariffs on fob export prices for 144 products, in which he used a separate index for semi-manufactures ( 44 articles) and manufactures (62 manufactured articles). 
5 yards to the $\mathrm{lb}$ has been assumed. See British Parliamentary Papers (I905), p. 29I.

(c) In the case of woollen and worsted piece goods, average weights have been estimated varying from $18 \mathrm{oz}$ to the yard for heavy broad woollen piece goods and worsted coatings to $5 \mathrm{oz}$ to the yard for mixed worsted stuffs. See British Parliamentary Papers (1905) p. 29 I.

(d) Equivalence for measurement of mass or weight: $\mathrm{I}$ ton $=20 \mathrm{cwt}$; I cwt $=$ I $2 \mathrm{lb}=50.8 \mathrm{~kg}$; IO० yard $=20 \mathrm{lb} ; \mathrm{I} \mathrm{oz}=\mathrm{I} / \mathrm{I} 6 \mathrm{lb} ; \mathrm{I} \mathrm{lb}=0.453 \mathrm{~kg}$.

(e) Official equivalence for monetary units: I pound $=20$ shillings $=240 \mathrm{~d}$; $\mathrm{I}$ shilling $=\mathrm{I} 2 \mathrm{~d}$.

Database available to researchers upon request.

Table AI. Groups, articles and prices taken as representative of British manufacture exports, 1875

\begin{tabular}{|c|c|c|c|}
\hline Group & Representative articles & $\begin{array}{l}\text { Value of British } \\
\text { exports I } 875 \\
\text { (thousand } \\
\text { pounds) }\end{array}$ & $\begin{array}{l}\text { Average export } \\
\text { value of these } \\
\text { articles I } 875\end{array}$ \\
\hline \multirow[t]{4}{*}{ Cotton yarns (a) } & & I2782 & \\
\hline & $\begin{array}{l}\text { I. Cotton single } \\
\text { unbleached }\end{array}$ & & $9 \mathrm{~d} / \mathrm{lb}$ \\
\hline & $\begin{array}{l}\text { 2. Cotton single } \\
\text { undyed }\end{array}$ & & $20 \mathrm{~d} / \mathrm{lb}$ \\
\hline & $\begin{array}{l}\text { 3. Cotton double } \\
\text { undyed }\end{array}$ & & $23 \mathrm{~d} / \mathrm{lb}$ \\
\hline \multirow[t]{2}{*}{$\begin{array}{l}\text { Cotton manufactures } \\
\text { (b) }\end{array}$} & $\begin{array}{l}\text { 4. Cotton piece } \\
\text { bleached }\end{array}$ & 31454 & I988d/cwt (d) \\
\hline & $\begin{array}{l}\text { 5. Cotton piece } \\
\text { printed }\end{array}$ & I8494 & 266Id/cwt (d) \\
\hline $\begin{array}{l}\text { Woollen \& worsted } \\
\text { yarn }\end{array}$ & $\begin{array}{l}\text { 6. Woollen and } \\
\text { worsted yarn } \\
\text { undyed }\end{array}$ & 4417 & $6 o d / 1 b$ \\
\hline $\begin{array}{l}\text { Woollen \& worsted } \\
\text { manufacture(c) }\end{array}$ & $\begin{array}{l}\text { 7. Woollen stuffs all } \\
\text { wool }\end{array}$ & I8603 & 4594d/cwt (d) \\
\hline \multirow[t]{4}{*}{ Linen yarn (lbs) } & & I 450 & \\
\hline & $\begin{array}{l}\text { 8. Linen yarns } \\
\text { unbleached }\end{array}$ & & $20 \mathrm{~d} / \mathrm{lb}$ \\
\hline & 9. Linen yarns single & & $26 \mathrm{~d} / \mathrm{lb}$ \\
\hline & Io. Linen yarns double & & $46 \mathrm{~d} / 1 \mathrm{~b}$ \\
\hline Silk (thrown) & II. Silk thrown & IO8I & $80 o d / 1 b$ \\
\hline Jute manufactures & $\begin{array}{l}\text { I2. Jute canvas and } \\
\text { sacking }\end{array}$ & $\mathrm{I} 2 \mathrm{I} 2$ & $4 \mathrm{~d} / \mathrm{lb}$ \\
\hline
\end{tabular}


Table Ar. Continued

\begin{tabular}{|c|c|c|c|}
\hline Group & Representative articles & $\begin{array}{l}\text { Value of British } \\
\text { exports I } 875 \\
\text { (thousand } \\
\text { pounds) }\end{array}$ & $\begin{array}{l}\text { Average export } \\
\text { values of these } \\
\text { articles } \mathrm{I} 875\end{array}$ \\
\hline $\begin{array}{l}\text { Iron and steel } \\
\text { manufactures }\end{array}$ & $\begin{array}{l}\text { I3. Pig iron } \\
\text { I4. Bars \& angle } \\
\text { I5. Rails including steel } \\
\text { rails }\end{array}$ & $\begin{array}{r}2842 \\
\text { I } 7382 \\
\text { IO225 }\end{array}$ & $\begin{array}{l}\text { I200d/ton } \\
\text { I680d/ton } \\
\text { I68od/ton }\end{array}$ \\
\hline $\begin{array}{l}\text { Machinery hardware } \\
\quad \& \mathrm{c}\end{array}$ & $\begin{array}{l}\text { I6. Textile machinery } \\
\text { I7. Locomotive } \\
\text { machinery } \\
\text { I8. Sewing machinery }\end{array}$ & $\begin{array}{r}1383 \\
556 \\
518\end{array}$ & $\begin{array}{l}588 \mathrm{~d} / \mathrm{cwt} \\
540 \mathrm{~d} / \mathrm{cwt} \\
\text { I620d/cwt }\end{array}$ \\
\hline Copper manufactures & $\begin{array}{l}\text { I9. Copper lingots, } \\
\text { cakes, slabs }\end{array}$ & 983 & I9200d/ton \\
\hline $\begin{array}{l}\text { Leather and related } \\
\text { manufactures }\end{array}$ & $\begin{array}{l}\text { 20. Ox \& cow hides } \\
\text { 21. Calf skins }\end{array}$ & 2945 & $\begin{array}{l}26 \mathrm{~d} / 1 \mathrm{~b} \\
46 \mathrm{~d} / 1 \mathrm{~b}\end{array}$ \\
\hline $\begin{array}{l}\text { Alkali chemical } \\
\text { products }\end{array}$ & $\begin{array}{l}\text { 22. Bicarbonate of soda } \\
\text { 23. Caustic soda } \\
\text { 24. Soda crystals }\end{array}$ & 2223 & $\begin{array}{l}228 \mathrm{~d} / \mathrm{cwt} \\
28 \mathrm{od} / \mathrm{cwt} \\
82 \mathrm{~d} / \mathrm{cwt}\end{array}$ \\
\hline Paper manufactures & $\begin{array}{l}\text { 25. Paper for writing } \\
\text { 26. Paper for printing }\end{array}$ & 1020 & $\begin{array}{l}6 \mathrm{~d} / 1 \mathrm{lb} \\
4 \mathrm{~d} / \mathrm{lb}\end{array}$ \\
\hline
\end{tabular}


Table A2. Variables and data used in the tariff-growth regressions 
Table A2. Continued

\begin{tabular}{|c|c|c|c|c|c|c|c|c|c|c|c|c|c|c|}
\hline COUNTRY & ${ }_{75} \mathrm{NT}$ & 70GDPpc & $\begin{array}{l}7013 \\
\text { GDPGR } \\
\end{array}$ & 75NTMAN & 75UNTMAN & $\begin{array}{l}\text { 75Dif } \\
\text { Skill } \\
\end{array}$ & $\begin{array}{l}75 \text { Corr } \\
\text { Skill } \\
\end{array}$ & ${ }_{75}$ POLT 2 & 75XCONS & 75INST & $\begin{array}{l}\text { Dum } \\
\text { Land }\end{array}$ & $\begin{array}{l}\text { Dum } \\
\text { Rich }\end{array}$ & $\begin{array}{l}\text { Dum } \\
\text { Ind }\end{array}$ & $\begin{array}{l}\text { Dum } \\
\text { Reg }\end{array}$ \\
\hline$\overline{\text { BUR }}$ & 3.6 & 503.9 & 0.72 & & & & & & & & 0 & 0 & 0 & 4 \\
\hline CEY & 6.0 & 851.4 & 0.87 & 4.I & 3.9 & 0.02 & $0.2 \mathrm{I}$ & & & & ○ & ○ & ○ & 4 \\
\hline CHI & $3 \cdot 3$ & 530.0 & 0.10 & & & & & -6.00 & 1.00 & -2.50 & ○ & ○ & ० & 4 \\
\hline EGY & 7.4 & 648.7 & 0.77 & & & & & & & & o & ○ & ० & 4 \\
\hline IND & 3.0 & 533.1 & 0.54 & 2.7 & 2.8 & 0.02 & 0.36 & & & & o & ○ & ० & 4 \\
\hline INDO & 4.9 & 654.5 & 0.75 & & & & & & & & o & ○ & ० & 4 \\
\hline JAM & & $535 . \mathrm{I}$ & 0.30 & 10.3 & $\mathrm{I} 2.5$ & 0.00 & -0.20 & & & & ० & ○ & ० & 4 \\
\hline JAP & 8.3 & 737.4 & I. 48 & 0.0 & 0.0 & & & 1.00 & 7.00 & 4.00 & ० & ० & o & 4 \\
\hline MAR & & 563.0 & 0.54 & 5.7 & 9.2 & 0.02 & -0.04 & -6 & I & & o & ○ & ० & 4 \\
\hline PHI & 7.8 & 776.0 & $0.7 \mathrm{I}$ & 0.0 & 0.0 & & & & & & o & o & o & 4 \\
\hline SOU & & 857.9 & I. 46 & $8 . \mathrm{I}$ & 9.0 & 0.00 & $-0.5 \mathrm{I}$ & 4.00 & 7.00 & 5.50 & 0 & o & o & 4 \\
\hline THA & 3.0 & 712.0 & 0.39 & & & & & & & & o & ○ & ० & 4 \\
\hline TUN & & 632.7 & 0.78 & 4.6 & $7 \cdot 3$ & 0.01 & -0.04 & & & & 0 & o & o & 4 \\
\hline TUR & 7.4 & 825.0 & 0.90 & 7.7 & 6.3 & -0.02 & -0.49 & -10.00 & 1.00 & -4.50 & o & ○ & ० & 4 \\
\hline
\end{tabular}

Recognition of variables used in Table A2

75NT Tariff average, I2 years from I865 to I875. Most of them came from Clements and Williamson's (200I) database.

70GDPpc Maddison (2003) I870 real per capita GDP.

7013GDPGR Acumulated rate of growth between 1870 and I913

75NTMAN Weighted industrial tariff of 1875, using total manufacture British export shares from database Appendix 2.

75UNTMAN Unweighted industrial tariff average from database Appendix 2.

75Dif Skil Calculated as the difference between the simple average of the ad valorem tariffs of the respective skill-intensive sectors ('up cut-off') and the non-skill-intensive sectors ('down cut off') by country.

${ }_{75}$ Corr Skill Correlation between skill and tariff rankings of the industrial sector by country.

75POLT2 Range (numeric) $=-$ Io to Io ( - IO $=$ high autocracy; Io $=$ high democracy) in 1875 .

75XCONS Executive constraints (numeric): operational (de facto) independence of chief executive in 1875

75INST An average of 75 XPOL2 and 75 XCONS

DumLand Dummy Land: Rich New Settlers $=1$; the others $=0$.

DumRich Countries with GDP per capita bigger than half UK in $1870=\mathrm{I}$; the others $=0$.

DumInd Countries with independent commercial policy $=\mathrm{I}$; the others $=0$

DumReg Rich Europe $=\mathrm{I}$; rich land abundant $=2$; poor independent countries $=3$; poor dependent countries $=4$.

Method and sources: see Section 4 of the text, and Appendix. 
Table A3. Matrix correlation between variables of Table A2

\begin{tabular}{lcccc}
\hline \hline & 75 DIFfSKILL & $75 \mathrm{NT}$ & $75 \mathrm{UNTMAN}$ & \multicolumn{1}{c}{ 75XCONS } \\
\hline 75DIFfSKILL & $\mathrm{I} .00$ & -0.87 & $-0.9 \mathrm{I}$ & 0.23 \\
75NT & -0.87 & $\mathrm{I} .00$ & 0.84 & -0.23 \\
75UNTMAN & $-0.9 \mathrm{I}$ & 0.84 & $\mathrm{I} .00$ & -0.27 \\
75XCONS & 0.23 & -0.23 & -0.27 & 1.00 \\
\hline \hline
\end{tabular}

